\title{
Zenés sportok Cheer és ami mögötte van
}

\section{Music-related sports - Cheer and what lays behind}

\begin{abstract}
Zene és ... Mivel kapcsoljuk össze a zenét, mint jellegzetes kulturális elemet, amikor zenés rekreációs programokról beszélünk?

Amennyiben a szellemi rekreáció kerül előtérbe, akkor jellemzően az énekléssel, a zenehallgatással, a zenés színpadi produkciók megtekintésével hozzuk párhuzamba.
\end{abstract}

A mozgásos rekreáció területén azonban sokkal árnyaltabb kép kerül az olvasó elé: elsődlegesen a tánc különböző válfajai, akár néptánc, latin és standard társastánc, akrobatikus rock and roll, klasszikus balett, jazz, kortárs, hip-hop, divat- és sport táncok, jégtánc, zumba; a sportosabb változatok között nevesítve az aerobik, verseny fitness, ritmikus gimnasztika, pole fitness, szinkron úszás; vagy éppenséggel a mazsorett, a capoeira.

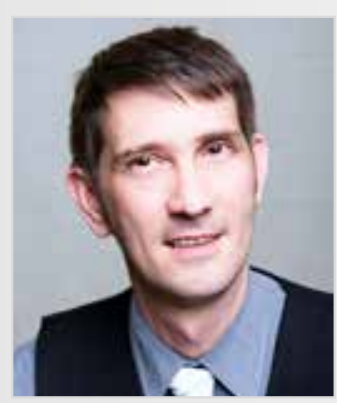

MAGYAR MÁRTON sZerző Munkahelye: ELTE Egészségfejlesztési és Sporttudományi Intézet Beosztás: egyetemi tanársegéd Levelezési cím: 1117 Budapest, Bogdánfy u. 10/B. Telefon: +36-1/209-0619 E-mail:magyar.marton@ppk.elte.hu Érdeklődési kör: animáció, turizmus, zene, tánc, úszás Fotó: Hámori Zsófia
A Magyar Divat- és Sporttánc Szövetség égisze alá tartoznak a színpadi táncok (showtánc, jazz tánc, sztepp, akrobatikus tánc, balett, modern, folk, hastánc, flamenco, karaktertánc...), az utcai táncok (hip hop, disco dance, electric boogie, break dance, techno...) és az ún. „speciális páros táncok" (argentín tangó, Mambo, Salsa, Merengue, Bachata, Jitterbug, Hustle/Disco Fox, West Coast Swing...), összesen több mint 30 tánckategória (MDSSZ, é.n.).

$\mathrm{S}$ ott szerepel a zenés mozgásformák sorában a cheer is, amely sokak szemében elsô gondolatra a pompon lányok show-produkciójával kapcsolódik össze, jellemzően amerikai sportversenyek kezdetén.

Lehet, hogy nem is áll ez annyira messze a valóságtól. Ám ennél többet jelent a cheer, mint összetett mozgásforma.

Talán hazánkban a legfiatalabb zenés mozgásformaként

A Cheerleading Szabadidősport Szövetség 2013 májusában alakult meg 6 egyesület konszenzusával, mára 14 tagegyesületet számlál; székhelye Érden található. A sportág jellegzetesen kapcsolódik az egyetemi sportélethez, ennek egyik bizonyítéka például, hogy a 2018. évi Egyetemi Világjátékokon már a Cheerleading is jelen lesz (Magyar Cheer Szövetség, 2017), másrészt pedig az, hogy az egyetemi sporthoz szervesen kötődik a szövetség vezetőségének munkássága: az egyik alelnök, Kovácsik Rita is az ELTE színeiben szerzett versenyzői sikereket például Miklós Mátyással a 2015 szeptemberi European Openen összesítésben a 4., az európai párosok között pedig az ezüst érmet megszerezve; illetve 2009 óta vezeti az ELTE Cheerleader csapatát, amely eredeti célja a futsal csapat versenyeken való buzdítása volt.

Az ELTE SE hazánk jelenleg legsikeresebb cheer szakosztálya. ismert a cheer.

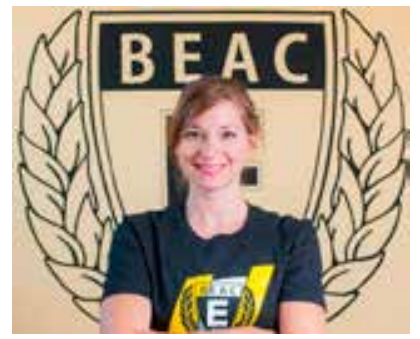

Kovácsik Rita:

- Cheerleading Szabadidősport Szövetség alelnöke

- Európai Cheer Szövetség (ECU) Sportolói Bizottságának tagja - BEAC Aerobik Szakosztály vezető - BEAC Cheerleader Szakosztály vezetőedzó

- European Open 2015 összesített 4. hely, európai párosok között 2. hely

- válogatott keret tag (2014) E-mail: rita.kovacsik@hotmail. com

Fotó: Simó Szabolcs

\section{Tekintsünk hát bele a cheer} sportág világába!

A cheerleading szoros kapcsolatban áll történelmi fejlődését tekintve az amerikai sportokkal (pl. amerikaifoci, kosárlabda és rögbi). Az első egyetemi amerikai futball meccs, amely 1869-ben a Princeton University és a házigazda Rutgers University között Piscataway városban került megrendezésre, jelentette az első lépéseket a sportág megszületésében. Ezekben az időkben a Princeton amerikai foci meccseinek hangulata sarkallta arra a hallgatóit, hogy egy csak férfiakból álló „élénkítő klubot” hozzanak létre, a "cheers" (vagyis a „chants” és „yells” szavak egyesítéséből, azaz a kántáló beszéd és ordítás egysége) levezénylésére. Az egyedi koncepció elterjesztésére 1884ben a lediplomázott Thomas Peebles Minneapolisba költözött, ahol az egyetemen bemutatta ezt a módszert, és óriási sikere támadt. Ebben az évben a Minnesotai Egyetemen az amerikai foci mellett már a rugby meccseken is alkalmazták sajátságos szavaikat (SKI-YOU$M A H$, utalva az egyetem nevére és egy ősi amerikai csatakiáltásra). Ezek után terjedt el szélesebb körben is az USA-
A Cheerleading Szabadidősport Szövetség tagjai:

1. Budai Akrobatikus Sport Egyesület (Budapest)

2. Debreceni Egyetem UD Cheerleaders

3. Diamond Cheer Dance (Pomáz)

4. Dream Team Cheerleaders (Gyöngyös)

5. ELTE SE (Budapest)

6. Érdi Torna Club

7. Flip Unit Team (Szeged)

8. Miskolc Steeleaders

9. Molnár Ferenc Általános Iskola (Budapest, IX. ker.)

10. Óbudai Egyetem (Budapest)

11. Semmelweis Egyetem Egészségtudományi Kar (Budapest)

12. Sharks Ladies (Győr)

13. Spartan Cheerleaders Sportegyesület (Dunaújváros)

14. Vivace Táncegyesület (Budaörs)

ban. 1898-ban Jack „Johnny” Campbell, a Minnesotai Egyetem egyik diákja újdonságnak számító módon megafont is használt a buzdításra. A beltéri meccsek között 1891-től a kosárlabda esetén kezdték el alkalmazni a cheerleadinget. 1923-tól szerepeltek nők is a cheerleadingben, amelynek megjelenése szintén a Minnesotai Egyetemhez kötődik. 1940től többségében már nők vettek részt benne. Az 1920-as évektől jelentek meg a különféle atletikus elemek, talajgyakorlatok és táncok. Az 1960-as évektől gyakorlatilag minden amerikai középiskolában megtalálható. Az amerikai szövetség ( $N C A=N a-$ tional Cheerleaders Association) 1961-ben alakult meg, s szervezett táborokat a cheerleading szerelmeseinek. Az 1970-es években vezették be a páros emeléseket (partner stunts) és piramisokat a látványosság érdekében. 1975-től a zene is beépült a gyakorlatokba. 1974-ben létrejött a Egyetemes Cheerleading Szövetség (UCA = Universal Cheerleaders Association), amely 1982-ben megrendezte az első Nemzeti Cheerleading Bajnokságot, melyet az ESPN (Entertainment Sports Programming Network) csatorna közvetített a televízióban. Ezzel az amerikai televíziózásban egy három évtizedes korszak kezdődött, középpontban a cheerleadinggel. Ennek hatására a bajnokságok, zenei videók és sportesemények további fejlődése indulhatott el a világ számos országában. 1987-ben megalakult a cheerleader edzők és ügyintézők amerikai szövetsége (AACCA = American Association of Cheerleading Coaches and Administrators), amely azóta is ellátja a cheer sport biztonsági szabályainak kialakítá- 
sát. 1988-tól Japánban, 1989tôl az Egyesült Királyságban, majd az 1990-es években az európai országokban is megjelent a cheer. Az 1996. évi atlantai nyári olimpiai játékok nyitó ceremóniáján is megjelent a cheerleading (ICU, é.n.). Azóta a sportág jelentős fejlődést tudhat magáénak, amelynek eredményeképpen 2016-ban ideiglenes olimpiai sportági elismerést kapott, akárcsak a Muay Thai (IOC, 2016). 2004-től rendeznek a sportágban világbajnokságot az orlandói Walt Disney Resortban (ICU, é.n.), ahol 2017-ben 70 ország versenyzett. Az európai bajnokságok sorában pedig a 2017. évi a hetedik volt.

Napjainkban számos lehetőség nyílik a cheerleading müvelésére. Nagy-Kismarci Bence szerint ez egy többtényezős modell, melynek alapjai közé tartozik az érdeklődési kör, a tehetség és az elkötelezettségi szint. Lehet valaki a középiskolájának szurkoló cheerleader, egy nemzeti csapatnak a hivatásos sportolója, vagy éppen a hazáját reprezentáló válogatott kerettag a nemzetközi megmérettetéseken. Többségében nők (82\%), 20-25 év közöttiek (65\%) végzik ezt a sportot Magyarországon (Nagy-Kismarci, 2016).

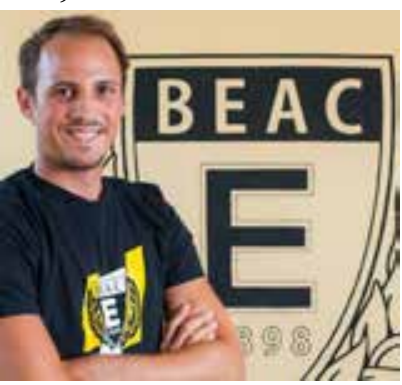

Nagy-Kismarci Bence:

- BEAC Cheerleader Szakosztály sportszervező, segédedzó

- SE Cheerleaders vezetőedzó

- a Magyar All Girl Válogatott edzője a 2016/2017.

és a 2017/2018. évadban

- Coed Group Stunt és Coed Team kategóriában Európa-bajnoki 2. és 3 . hely

- többszörös magyar bajnok E-mail: nkbence@gmail.com Fotó: Simó Szabolcs

Gerlei Anna, az ELTE Cheerleading Szakosztály hallgatói kapcsolattartója elmondása szerint habár a cheer dancerek (performance cheer táncosok) is használnak (kisebb) pomponokat, nem egyenlő a pomponlányokkal (Sideline cheerleading), akiknek a teljesítménye a meccseken a közönség szórakoztatása, általá-

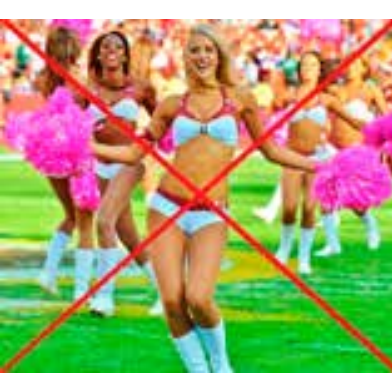

Cheer Táncos

(Performance cheerleader) nem pompon lány Cheer Dancer

(Performance cheerleader) is not a pom-pom girl Forrása: Gerlei Anna

ban kissé hiányos öltözékben, és nem minősülnek sportolóknak.

A Competitive Cheerleading kifejezés alatt két sportág található: Cheer Dance és az akrobatikus cheerleading.

A Cheer Dance tánc alapú sportág, amely alapjait a klaszszikus és jazzbalett jelentheti. Itt előnyt jelenthet a táncos, balettos múlt. A koreográfiákban ugrások, forgások találhatók (ELTE Cheerleading, é.n.b), nincs benne akrobatika. A Cheer Dancerek forgócipóben (és nem magas szárú csizmában) táncolnak, amely egy olyan bőrből készült tánccipő, amely fedi a lábfej és a talp elülső részét, ám a nagyobb tapadás érdekében szabadon hagyja a sarkat. Ezzel akár 16-20 forgás is lehetséges. A lányok többnyire hosszú ujjú, rövid szoknyás tornadresszt, a fiúk a versenytáncosokéhoz hasonló ruhát viselnek. Kétféle kategória létezik: a team és a páros. A ,small' (4-9 fó) és a ,medium ' (10-15 fó) mellett létezik a ,large' (16-25 fó) csapat, fiúk és lányok vegyesen szerepelhetnek benne (wikipedia, 2017). Az ELTE SE csapata 15-20 fős. Duóban (double) jellemzően két lány táncol együtt, ám lehet egy fiú és egy lány, illetve két fiú is párban. Azonban a cheer dance jellemzően (98\%) a lányok sportága. It is meghatározó az előadásmód, a táncosok arcki-
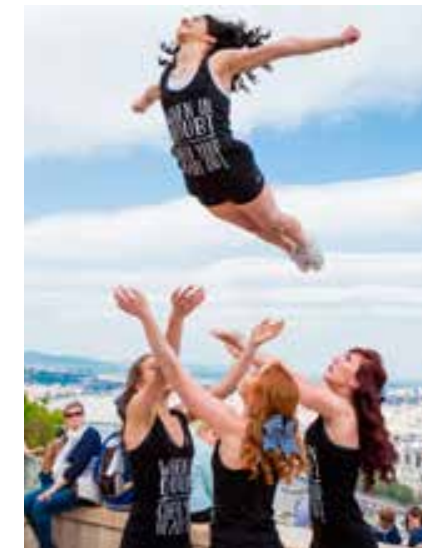

Dobás - ELTE Cheerleading Dobas - ELTE Cheerleading Forrása: Tóth József fotómúvész (Figura Photo)

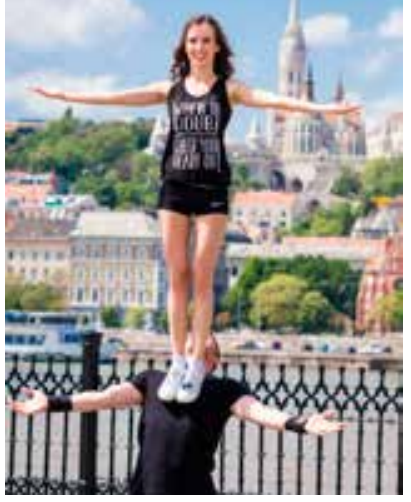

Páros Emelés - ELTE Cheerleading Partner Stunt - ELTE Cheerleading Tóth József fotómúvész (Figura Photo)

fejezése, a látványos térformák kialakítása (Gerlei Anna).

$\mathrm{Az}$ akrobatikus cheerleading a cirkusz látványvilágához hasonlít; szerepel benne flick, rundel, szaltók, szaltó és duplé dobások (Reggeli Start, 2014). Gerlei Anna kiemeli az „akrósok” szaknyelvből még a stuntok (emelések), a jumpok (ugrások), a piramisok, a basketok (dobások) és a tumbling (talajakrobatika) kifejezését. Az utóbbi három csak a teamek routinjában szerepel (wikipedia, 2017). A több méter magas dobások és piramisok kialakítása kapcsán hasznos lehet a tornász múlt, ám kezdő fiúk és lányok is elkezdhetik a sportágat, akár az egyetemi általános testnevelés kurzus kereteiben (BEAC, 2017).

A cheerleading versenyek legnagyobb és leglátványosabb kategóriája a teamek, ahol 12-25 fó versenyez; s gyakorlatuk kötelező eleme egy minimum 30 másodperces szurkolás is, ahol kellékeket (pompon, tábla, megafon) is használnak (wikipedia 2017). A coed teamekben fiúk és lányok ideális esetben fele-fele arányban szerepelnek, az all girl teamekben kizárólag lányok.

A group stunt 3-5 fős csapatokat jelöl, coed vagy all girl alkategóriában. Egy átlagos 4-fós groupban van egy flyer, akit emelnek, (általában a legkönnyebb lány, de fiú is lehet), két base (tartó ember), akik egymással szemben állva emelnek vagy dobnak, és egy backspot (általában a legmagasabb ember a csapatban), aki hátulról biztosítja az emelést.

A legkisebb létszámú kategória a partner stunt (páros), ahol egy fiú emel egy lányt. A fiúk számára gyakran ez a kategória a legvonzóbb, mert itt van a szükségük a legnagyobb erőnlétre és a legjobb technikákra. Itt szükség van ún. külső spot- terekre (biztosító emberekre), akik baj esetén elkapják a flyert. A szabályok szerint minden versenyszámhoz szükségesek spotterek (Gerlei Anna).

$\mathrm{Az}$ akrobatikus cheerleaderek sportcipóket viselnek. A flyerek cipőjének talpkialakítása gyakran olyan, amely megkönnyíti az emeléseknél a fogást (wikipedia, 2017).

A cheerleading produkciókban jelentős szerepe van a zene helyes megválasztásának. Delp (é.n.) szerint a cheerleading zene szerkesztett zenék egyvelege, amelyhez általában különböző hangeffekteket adnak. Azonban a túl sok effekt negatív hatású lehet. A zene tempója általában 138-145 bpm közötti, amely a nagyon gyors és izgalmas produkcióhoz szükséges. Ehhez az eredeti dalokat lehet, hogy fel kell gyorsítani.

A bírók nézőpontjából fontos a nem megszokott zenerészletek használata is. A legtöbb csapat a legfrissebb hiphop zeneszámokat használja, habár más stílusok is sikeresen alkalmazhatók. Minimum 3/8,

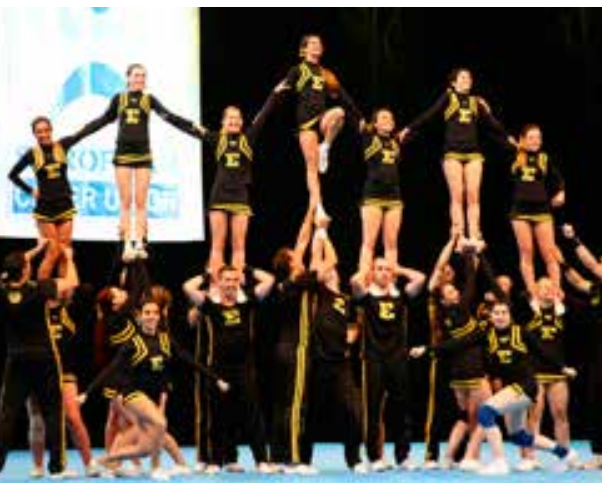

ELTE Coed Team -

Európa-bajnokság 2017, Prága European Championship 2017, Prague

Forrása: https://www.beac.hu

de maximum $6 / 8$ ütemű zenék javasoltak. Fontos, hogy a zenemix és a koreográfia együtt legyen. Williams (2014) szerint a cheer zene kiválasztásában szerepet játszik a cheerleaderek életkora és az esemény jellege. 3 alapszabályt hangsúlyoz a megfelelő zene kiválasztásánál: alkalomhoz illőség, „helyén valóság” (csúnya szavaktól mentes, szexuális tartalomtól mentes), egyediség (ne a népszerü, sokak által ismert és használt zenét alkalmazzuk), esemény- / téma-specifikusság (ha létezik olyan dal, amely illik a csapathoz). Véleménye szerint a hiphop, rap és a klasszikus rock zene alkalmas, jól táncolható ütemezésű. Fiatalabb cheerlea- 
derek produkcióihoz ajánlja a Disney-előadókat, így például Selene Gomez, Hannah Montana, Miley Cirus, vagy Demi Lovato dalait. $\mathrm{Az}$ idősebb cheerleaderek performanszaihoz alkalmasnak találja a Pussycat Dolls, Rihanna, Pink, a Black Eyes, Beyonce, Eminem vagy Queen dalait.

A sportág egyre sikeresebb magyar színekben hazai és nemzetközi porondon egyaránt. 2016-ban szerepelt hazánk először Világbajnokságon: 19 induló közül a 15. helyen végzett a magyar páros (Szabó Hanna, Balogh Patrícia) a Team Cheer - Freestyle Pom Doubles kategóriában (ICU, 2016), míg idén a 23 induló közül ugyanezen kategóriában a 16. helyen végeztek $(I C U, 2017)$.

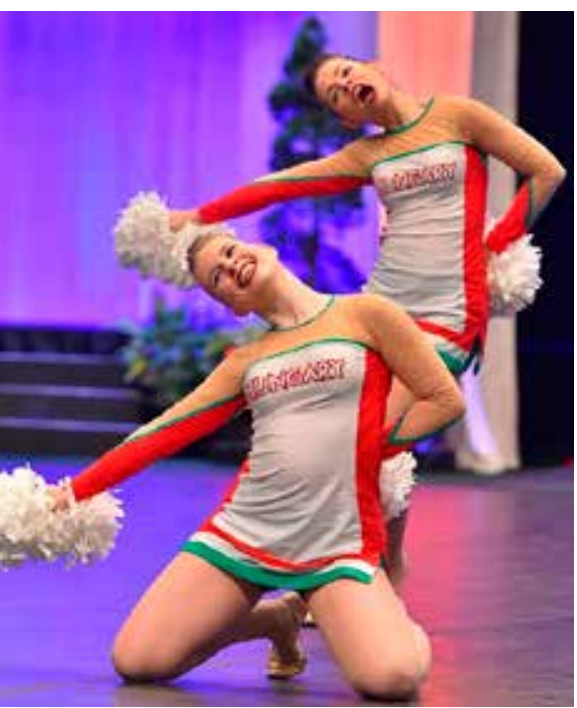

Balogh Patrícia és Szabó Hanna a 2016. évi világbajnokságon Patrícia Balogh and Hanna Szabó on the World Championship 2016 Forrása: http://www.

hungariancheerunion.hu

A Prágában megrendezett 2017. évi Európa-bajnokságon „Senior Allgirl Elite” kategóriában a Hungarian National All Girl Team a 3. helyet szerezte meg, a cseh Lady Eagles pedig az 1. helyet. Ugyanezen a versenyen "Senior Coed Elite" kategóriában a dicsőséges 5 . helyet az ELTE Coed Team, a 9. helyet pedig a Spartan Warriors (Dunaújváros) kapta. A „Senior Freestyle Pom Teams" kategória 16. helye az ELTE Cheer Dance Team, a 22. hely a Shark Ladies Dance Team csapatáé (ECU, 2017).

A 2016. évi Bécsi EB-n az ELTE Coed Team „Senior Coed Elite” kategóriában a dicsőséges ezüstérmet szerezte meg. „Senior Coed Group Stunt” kategóriában az ELTE Coed Gro-

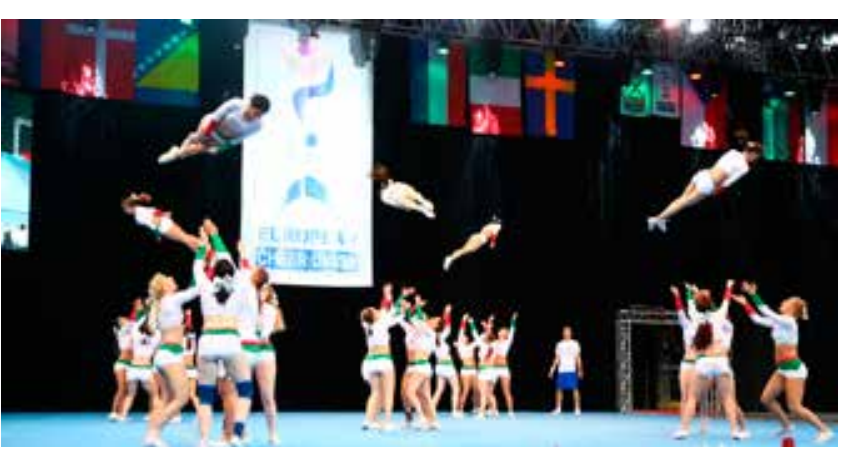

A Magyar Női Válogatott - Európa-bajnokság 2017, Prága The Hungarian National All Girl Team

- European Championship 2017, Prague

Forrása: Team Hungary All Girl facebook

up a dobogó 3. fokán végzett, kategória-győztes a belga csapat volt. Az ELTE Cheer Double (Szabó-Balogh) hozta el a "Senior Freestyle Pom Doubles” kategória 7. helyét (1. hely: Szlovénia). A „Senior Partner Stunt" kategóriában az Ôsz Olivér - Báldy Fruzsina páros a 8 . helyen végzett, a győztes a szlovén duó lett. A hazai Spartan Katz csapata „Senior Allgirl Group Stunt" kategóriában 9. helyen végzett, a győzelem a norvégoké volt. Senior Jazz Doubles" kategóriában 1. helyen az oroszok, a 12. helyen az ELTE Jazz Double: Kovács Barbara - Botos Edgár végzett, a szintén orosz-győztes „Senior Hip Hop Teams" kategóriában a Best csapata a 14. helyen zárt. A Kovács Károly - Mundweil Kinga páros (ELTE Hip-Hop Double) a „Senior Hip Hop Doubles" kategória 15 . helyét hozta Magyarország számára (1. hely: oroszok). „Senior Freestyle Pom Teams" kategóriában két magyar siker született: az ELTE Cheer Dance Team a 14. helyen végzett, míg a Vivace Girl's csapata a 19. helyen (győztes: osztrákok). A „Junior Jazz Teams" kategória magyar eredménye: a Harmony Team a 15. helyen végzett, a kategóriagyőztes az orosz csapat lett (ECU, 2016).

Kifejezetten illik a zenés rekreációs programok körébe a cheer mindkét ága. Az edzések rekreációs felépítésűek, edzéstani sajátosságokkal. Bemelegítés után a táncosok egyes mozdulatokat, ugrásokat, forgásokat gyakorolnak, versenyidőszakban többnyire koreográfiát tanulnak. Az akrósok kisebb egységekben (group és partnerek) szintüknek megfelelően gyakorolnak, verseny előtt ők is a koreográfiát csiszolgatják. Emelések mindig szivacson történnek. Új, nehezebb elemek megtanulásakor egymásnak is spottolnak (biztosítanak). Igazi csapatmunka ez, amelyben a bizalomnak kitüntetett szerepe van. A csapattagok többféle közös szabadidős tevékenységet is végeznek együtt (Gerlei Anna). A 'nemi keveredés' pedagógiai szereppel bír a régi nemekhez kötődő normák megváltoztatásában (Priyadharshini

Pressland, 2015).

Számtalan eseményen lehet találkozni az ELTE Cheer Teammel. Táncos show, Sideline show, Akrobatikus show, Táncos és akrobatikus show és Cheerleading flashmob található meg a kínálatukban, amelyekkel 5-6o perc közötti, 4-30 fő közötti résztvevővel gazdagítják az egyes események repertoárját (ELTE Cheerleading, é.n.a). Részt vettek például az V. Pécs City Karneválon is, 2017. szeptember 16-án, ám találkozni velük világbajnokságokon is (hoki, triatlon, vizes), az EFOTT-on, különböző ELTE-n a szabadon választható kurzusok között, mint az Általános testnevelés egyik sportága évek óta töretlen sikernek örvend a hallgatók körében.

A sportág kipróbálásához kívánunk hozzájárulni az alábbi linkeken lévő videók megtekintésével:

ELTE Cheerleaders youtube csatornája: https://www.youtube. com/channel/UCTDgt31iPFAT com/channel/

ECU youtube csatornája: https://www. youtube.com/channel/ UC2y3FvR1MJrkh8hrEV9aDsw

ICU youtube csatornája: https://www.youtube.com/user/ IntiCheerUnion

Kovácsik Rita youtube csatornája: https://www. youtube.com/channel/ UCFQ8C2Vel5e6uhRmF3C9wYw promóciós rendezvényeken. Az
IRODALOMJEGYZEK

BEAC (2017) Zenés és táncos sportok. From: https://www.beac.hu/sportolni-szeretnek/sportagak/zenes-es-tancossportok/

Delp, V. (é.n.) Tips for Choosing Cheerleading Music. From: http:// cheerleading.lovetoknow.com/ Cheerleading_Music

ECU / European Cheer Union (2017) ECU European Cheerleading Championships 2016 (Vienna, Austria) Results. From: http://www.cheerunion wp-content/uploads/

ECU / European Cheer Union (2017) ECU European Cheerleading

Championships 2017 (Prague, Czech Republic) Results. From: http://www. cheerunion.eu/wp-content/ uploads/2017/01/ECU_Results_2017 Prague.pdf

ELTE Cheerleading (é.n.a) Fellépésszervezés. From: https://www.eltecheer.hu/ fellepesszervezes

ELTE Cheerleading (é.n.b) Mi az cheerleading? From: https://www. eltecheer.hu/

ICU / International Cheer Union (2016) 2016 World Cheerleading Championship Team Cheer - Freestyle Pom Doubles Results 2016. From: http://cheerunion. org/championships/

results/2016results/2016fpd/

ICU / International Cheer Union (2017) 2017 World Cheerleading Championship Freestyle Pom Doubles Results 2017. From: http://cheerunion.org/championships/ results/2017results/fpd/

ICU / International Cheer Union (é.n.) History of cheerleading. From: http:// cheerunion.org/history/cheerleading/ IOC/International Olympic Committee (2016) IOC Executive Board Wraps-Up First Day of Meetings. From: https://www.olympic.org/news/iocd-wraps-up-first-day-ofmetings

Magyar Cheer Szövetség (2017) Sportdiplomáciai siker. From: http://www. hungariancheerunion.hu/

MDSSZ (é.n.): A Magyar Divat- és Sporttánc Szövetség. From: http://www. mdssz.hu/page02.php?menu id=2\&cikk id $=8$

Nagy-Kismarci, B. (2016) A

cheerleading megjelenése és múködése Magyarországon. A sportág megítéléséne változása a kezdetektől napjainkig. MSc diplomadolgozat. Budapest: Testnevelési Egyetem

Priyadharshini,E. - Pressland, A. (2015) Doing femininities and masculinities in a 'feminized' sporting arena: the case of mixed-sex cheerleading. Sport in Society: Cultures, Commerce, Media, Politics. 19. 8-9. DOI:

10.1080/17430437.2015.1096253

Reggeli Start (2015) DIGI Sport, Reggeli Start - Miklós Mátyás, Kovácsik Rita. From: https://www.youtube.com/ watch?v=wJZZ7EODBTC

Wikipedia (2017) Cheerleading. From: https://hu.wikipedia.org/wiki/

Cheerleading\#Cheerleading_Magyarorsz. C3.A1gon

Williams, L. (2014) Good Songs for Cheer. From: http://cheerleading. lovetoknow.com/good-songs-cheer

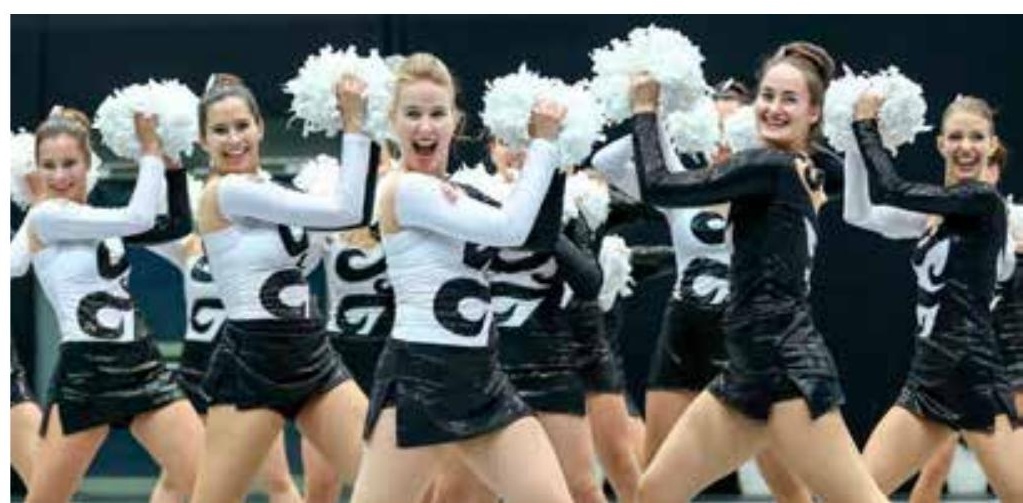

ELTE Cheer Dance Team, a 2016-os EB 14. helyezettje

ELTE Cheer Dance Team, 14th place on European Championship 2016 Forrása: https://www.beac.hu 